\title{
O ASSISTENTE DO MINISTÉRIO PÚBLICO: (I)LEGITIMIDADE PARA RECORRER
}

\section{THE ASSISTANT TO THE PUBLIC PROSECUTOR: (I) LEGITIMACY TO APPEAL}

\author{
Benhur Felipe Pedrozo ${ }^{1}$ \\ Patrícia Ribeiro Mombach ${ }^{2}$
}

Resumo: Sabemos que a Constituição Federal de 1988 consagrou no seu artigo 129, inciso I, como função privativa do Ministério Público, a promoção da ação penal de iniciativa pública. No entanto, o Código de Processo Penal de 1941 traz o instituto do assistente de acusação como um auxiliar do órgão ministerial para atuar nas ações penais de iniciativa pública. Assim, diante do conflito entre os referidos diplomas legais, torna-se imprescindível realizarmos uma discussão do instituto frente à ordem constitucional vigente, principalmente no que tange ao artigo 598 do Código de Processo Penal, que possibilita ao assistente de acusação interpor recurso mesmo nas hipóteses em que o órgão ministerial opte pela absolvição, ou tenha se conformado com eventuais sentenças condenatórias ou absolutórias. Portanto, o presente artigo tem como objetivo de evidenciarà comunidade jurídica o retrocesso que a figura do assistente de acusação representa frente ao Estado de direito após a Constituição Federal de 1988 e identificar a não recepção constitucional do artigo 598 do Código de Processo Penal.

Palavras-chave: Assistente. Ilegitimidade. Para Recorrer.

Abstract: We know that the Federal Constitution of 1988 enshrined in article 129, paragraph I, as a private function of the prosecution promoting prosecution of public initiative. However, the Criminal Procedure Code 1941 brings the institute's assistant prosecutor as an auxiliary organ of the ministry to work in the public prosecutions. Thus, in view of the conflict between these legal instruments, it is essential to conduct a discussion of the front institute the current constitu-

1 Advogado, bacharel em direito pela Universidade do Sul do Estado de Santa Catarina. E-mail: benhur.felipepz@gmail.com

2 Professora da Universidade do Sul do Estado de Santa Catarina, especialista e mestre em Ciências Criminais pela PUC/RS. Email: patriciamombach@yahoo.com.br. 
tional order, especially with regard to article 598 of the Criminal Procedure Code, which allows the prosecution assistant appeal even in cases where the ministerial body opts for acquittal or have settled for any condemnatory or absolving sentences. Therefore, this article aims to charge for the legal community rewinding the prosecution assistant figure is from the state of rights after the Federal Constitution of 1988 and identify non-constitutional receipt of article 598 of the Criminal Procedure Code.

Keeywords: Assistant. IIegitimacy. To Resort

\section{INTRODUÇÃO}

Para grande parte da doutrina e da jurisprudência, o assistente de acusação exerce a função de "terceiro interessado" no âmbito do processo penal, podendo atuar não só como auxiliar do Ministério Público, mas também substituí-lo nos casos de inércia do referido órgão estatal. No entanto, se faz necessário um estudo específico acerca do tema, uma vez que a Constituição da República Federativa do Brasil (artigo 129, I) incumbiu ao Ministério Público caráter privativo em promover ação penal de iniciativa pública, trazendo ao processo penal um caráter eminentemente público. Assim, indaga-se se nas situações em que o Ministério Público se der por satisfeito com uma sentença ou posicionar-se pela absolvição do acusado, se estaria o assistente legitimado a dar continuidade apercucio criminis, mesmo sem a presença do referido órgão acusador,nos termos do artigo 598 do Código de Processo Penal.

Adentrando ao ponto chave em discussão no presente artigo, serão demonstrados os posicionamentos que defendem a atuação da figura do assistente de acusação no processo penal brasileiro, tanto na doutrina como na jurisprudência contemporânea. Após, serão destacados os posicionamentos doutrinários que irão questionar a própria constitucionalidade da figura do assistente de acusação. Destacados tais apontamentos, dar-se-á inicio à discussão acerca do artigo 598 do Código de Processo Penal, que possibilita ao assistente de acusação promover re- 
curso nas hipóteses de inércia do órgão Ministerial.

\section{SISTEMAS PROCESSUAIS PENAIS E SUA INTERPRETAÇÃO CONSTITUCIONAL}

Para desenvolver o estudo sobre um determinado tema em destaque no Código de Processo Penal brasileiro, inicialmente é preciso constatar a sua conformidade com a Constituição Federal, ou seja, adequar o Código de Processo Penal à luz da Carta Magna de 1988, de forma a contextualizar o tema proposto à discussão, sob uma perspectiva constitucional.O presente estudo parte de uma análise sobre os sistemas processuais penais, para depois identificar o modelo adotado pelo Brasil, frente aos princípios regidos pela Constituição.

Sistemas processuais podem ser conceituados como pontos criados em um conjunto de princípios e regras constitucionais de acordo com a época política vivenciada em cada Estado, sendo que estes se unem em torno da aplicação do direito penal caso a caso. Assim, no Estado democrático de direito, em que é garantido o respeito ao cidadão frente às arbitrariedades estatais, aplicar-se-ão regras de um sistema acusatório, já no Estado totalitário e repressivo, o sistema inquisitivo encontra sua apreciação. (RANGEL, 2016).

Com origem nos regimes monárquicos, o sistema inquisitorial se aperfeiçoou a partir do século XVI até o século XVIII. Este modelo, que primeiramente foi criado como subsidiário do acusatório, posteriormente passou a substituí-lo, tornando-se uma espécie de ferramenta na busca de uma "verdade" através da tortura e abuso por parte do Estado. (RANGEL, 2016).

Marcos Alexandre Coelho Zilli destaca como sendo características do sistema inquisitorial:

1.Hierarquização da jurisdição: invariavelmente, o monarca é o depositário da jurisdição penal, que delega a fun- 
cionários subordinados, que a exercem em seu nome; 2. Presença do inquisidor: o poder de acusar e perseguir é exercido pelo mesmo órgão que também é encarregado de julgar 3. O acusado é tratado como um objeto de persecução e não como sujeito de direitos. 4 . O procedimento consiste em uma investigação secreta escrita e descontínua; 5. No campo probatório, impera o sistema das provas legais. Ou seja, a valoração das provas atende a rigorosos critérios que podem afastar ou reconhecer um fato como elemento hábil para a formação da convicção; 6 . O sistema e recursos reflete a forma hierarquizada de organização da jurisdição penal. Da mesma forma, que o monarca delega aos seus subordinados parcela da jurisdição que por eles é exercida, esta lhe é inteiramente devolvida quando do exame e julgamento do recurso. (ZILLI, 2003, p. 40).

Com origem no direito ateniense, o sistema acusatório não foi o único implementado na Grécia, porém, foi o primeiro modelo que estabeleceu garantia ao contraditório e primou pela oralidade. Entretanto, foi no período da modernidade que o Processo Penal passou por outras transformações, quando, sob influência das ideias liberais da Revolução Francesa e do mundo civilizado, adotou o sistema acusatório (FERRAJOLI, 2002).

Aury Lopes Junior afirma que na contemporaneidade o sistema acusatório é regido pelas seguintes características:

a) Clara distinção na função de acusar e julgar; b) A iniciativa probatória deve ser das partes (decorrência lógica da distinção entre as atividades); c) Mantém-se o juiz como um terceiro imparcial, alheio a labor de investigação e passivo no que se refere à coleta da prova, tanto de imputação como de descargo; d) Tratamento igualitário das partes (igualdade de oportunidades no processo); e) Procedimento é em regra oral (ou predominante); f) Plena publicidade de todo o procedimento (ou de sua maior parte); g) Contraditório e possibilidade de resistência (defesa); h) Ausência de uma tarifa probatória, sustentando-se a sentença pelo livre convencimento motivado do órgão jurisdicional; i) Institui- 
ção, atendendo a critérios de segurança jurídica (e social) da coisa julgada; j) Possibilidade de impugnar as decisões e o duplo grau de jurisdição. (LOPES JÚNIOR, 2017, p. 43).

$\mathrm{Na}$ atualidade, ao realizarmos uma leitura da Constituição Federal e dos princípios por ela destacados,como o contraditório, a ampla defesa, o duplo grau de jurisdição e a imparcialidade, entre outros, claramente extrair-se-á que o sistema adaptado na contemporaneidade é o acusatório. Todavia, razoável parcela da doutrina reconhece que o sistema adotado no Brasil é o sistema misto.

O sistema misto é assim denominado em razão de juntar em um único modelo características do sistema acusatório e inquisitório. Tendo em vista que o Processo Penal contempla uma investigação com reflexos inquisitoriais e, na fase judicial, prevê as garantias elencadas na Constituição, a doutrina majoritária entende que este é o modelo presente em nosso ordenamento jurídico. (LIMA, 2017).

Nesse sentido é o posicionamento de Renato Brasileiro Lima:

É chamado de sistema misto porquanto o processo se desdobra em duas fases distintas: a primeira fase é tipicamente inquisitorial, com instrução escrita e secreta, sem acusação e, por isso, sem contraditório. Nesta, objetiva-se apurar a materialidade e a autoria do fato delituoso. Na segunda fase, de caráter acusatório, o órgão acusador apresenta a acusação, o réu se defende e o juiz julga, vigorando, em regra, a publicidade e a oralidade. (Lima 2017, p. 41).

Contudo, outra parcela da doutrina (a qual nos filiamos) destaca que não basta realizar uma separação inicial entre as fases do processo e, posteriormente, permitir que as provas colhidas de maneira inquisitorial (na investigação) estejam à disposição do magistrado, ou ainda continuar aplicando regras estabelecidas no CPP, mesmo após a fase administrativa, sem 
antes realizar uma adequação constitucional de tal dispositivo.

Nesse sentido, assevera Paulo Rangel:

O certo, pensarmos seria oferecer a denúncia e extrair dos autos do processo o procedimento administrativo pré-processual. Ou seja, o inquérito policial. O Ministério Público deveria provar toda a acusação feita em sua peça exordial, com as provas que propôs, e somente as provas não renováveis permaneceriam nos autos; exemplo: as perícias em geral e os exames de corpo de delito. Do contrário, se assim não pensarmos, estaremos tapando o sol com a peneira. Chamando de sistema acusatório puro aquilo que sabemos efetivamente não ser. Há inclusive quem pense que o juiz pode condenar com base em provas apenas do inquérito policial, o que para nós, como vamos mostrar é inadmissível. (RANGEL, 2016, p. 55).

Não obstante, em razão de a Constituição Federal atribuir exclusivamente ao Ministério Público em caráter privativo a promoção da ação penal de iniciativa pública, bem como abarcar aos acusados à ampla defesa, contraditório e a presunção de inocência até o trânsito em julgado, é inegável que o modelo adotado pelo Brasil (mesmo que não expresso) definitivamente é o acusatório. Ocorre que, ao nos depararmos com as práticas processuais predominantes, mesmo tratando-sedos Tribunais Superiores, é preciso admitir que no Brasil prevalece uma promessa de um Código de Processo Penal com perspectivas democráticas, baseadas no sistema acusatório, que ainda não foram efetivadas. (RANGEL, 2016).

Assim, de nada adianta uma Constituição riquíssima em princípios e direitos, mas com carência em técnicas que permitam o controle e a neutralização do poder e do direito ilegítimo. Ou seja, precisa-se adequar o Código de Processo Penal aos direitos e garantias constitucionais, de modo que o ordenamento infraconstitucional seja reinterpretado em sentido constitucional, respeitando a pirâmide elaborada por Hans Kelsen, 
afastando o risco de olhar o novo sob a perspectiva do velho, estagnando qualquer avanço. (STRECK, 2000).

Portanto, é com a perspectiva de um processo baseado no sistema acusatório e suas características que devemos analisar o Processo Penal brasileiro e, por conseguinte, a figura do assistente de acusação.

\section{O MINISTÉRIO PÚBLICO E A SUA FUNÇÃO PRIVATIVA EM PROMOVER A AÇÃO PENALDE INICIATIVA PÚBLICA}

Conforme destacamos, uma das características que introduz o sistema acusatório é a divisão entre as funções do órgão acusador e julgador. Nesse sentido, o constituinte de 1988 atribuiu ao MP, em caráter privativo, a missão de promover a ação penal de iniciativa pública (artigo 129, inciso I).

Sobre a origem da instituição, majoritariamente prevalece o entendimento que o seu nascedouro adveio da ordenança francesa de Felipe IV, em 1302, ao destacar a atuação dos procuradores do rei. Entretanto, não caberá neste artigo realizar um estudo específico e profundo acerca da história e da evolução da instituição, uma vez que, apesar do tema ser instigante e de grande importância, demandaria uma pesquisa específica para revelar a evolução da instituição até os dias atuais. Neste momento, importa-nos destacar que o Ministério Público há muito tempo deixou de ser advogado do rei, para se tornar a instituição que hoje representa a defesa social. (BOSCHI, 1997).

Isto porque, após vedar a solução privada dos conflitos, o Estado assumiu para si a jurisdição, mas, não só isso, em matéria criminal passou a exercer o polo ativo da ação penal de natureza pública, atuando em favor de seu interesse ou dos particulares. Desta forma, tratando-se de ação penal de natureza pública, seja ela condicionada ou incondicionada, a legitimida- 
de ativa (regra geral) será composta pelo Ministério Público e, diferente do que ocorre no âmbito do processo civil (em que o autor incumbido de promover a ação é o titular do direito material), tal atribuição no processo penal é entregue ao Estado, o qual atuará por meio do Ministério Público. (MAZZILI, 2007; OLIVEIRA, 2016).

Atualmente é concedido ao Ministério Público uma atuação no órgão do poder judiciário, tendo a instituição garantias autônomas, orçamentárias e administrativas independentes. (BONFIM, 2017).

Todavia, a Constituição Federal de 1988 conferiu ao Ministério Público, em caráter privativo, a função de promover a ação penal de iniciativa pública (art. 129 I). Aqui é necessário destacar que o termo "promover" deve ser interpretado além do simples ato de dar início à ação penal de iniciativa pública. Suas atribuições vão se destacar, tanto na investigação criminal quanto na propositura de eventuais recursos decorrentes de uma decisão. (GRECO FILHO, 2010; POLASTRE LIMA 2013).

Tais garantias foram estabelecidas pela Constituição Federal de 1988, que após reconhecer amplos direitos fundamentais, envolvendo desde os individuais aos coletivos, constatou a necessidade de implementação e estruturação de seus órgãos, criando mecanismos a fim de garantir que os princípios e regramentos constitucionais fossem devidamente cumpridos. (SOUZA, 2007).

Nesse quadro, ressaltamos que apesar de o MP ter uma ampla liberdade em promover a ação penal, tal liberdade não se confunde com a faculdade de agir ou não. Neste sentido é o posicionamento de Geraldo Prado:

O simples fato de colocar o Ministério Público no lugar da vítima simboliza a impropriedade de pensar a ação penal nos moldes liberais de defesa de direitos disponíveis 
(origem da noção do direito de ação civil). Até mesmo nos sistemas jurídicos que adotam o princípio da oportunidade da ação penal pública (o Ministério Público tem margem de decisão sobre acusar ou não), a "liberdade" do Ministério Público é inconfundível com a "faculdade" do autor civil. A liberdade do Ministério Público estará sempre dirigida pelo princípio da legalidade, protegendo a comunidade das decisões pessoais de cada integrante da referida instituição, enquanto as motivações estritamente pessoais podem afetar na base da decisão de não se promover a ação civil clássica. (PRADO, 2007 p. 113).

Portanto, ao ser legitimado para agir pelo interesse da sociedade, não cabe ao órgão do MP o poder de escolha entre agir ou não (conforme detém o autor da ação no âmbito do processo civil), mas sim, o dever de agir nos casos determinados por lei. (MARQUES, 2000).

Entretanto, em casos de eventuais omissões quanto ao direito de ação no prazo em que lhe foi conferido, a própria Constituição Federal no art. $5^{\circ}$ LIX, atribuiu ao particular, por meio de ação penal privada subsidiária, a titularidade ao exercício do direito de ação (AVENA, 2017).

Finalmente, com a concepção de um processo penal sistemático, com garantias democráticas e, dando em conta a função privativa constitucionalmente conferida ao Ministério Público, dar-se-á inicio ao estudo sobre da figura do assistente de acusação.

\section{O ASSISTENTE DO MINISTÉRIO PÚBLICO: ASPECTOS CONSTITUCIONAIS E (I) LEGITIMIDADE PARA INTERPOSIÇÃO DE RECURSO}

Grande parte dos manuais de direito, ao realizar um estudo acerca da figura do assistente, por muitas vezes, deixa de des- 
tacar que o seu nascedouro adveio de um momento histórico em que o órgão ministerial não estava devidamente estruturado para atender os anseios da sociedade, razão pela qual, a fim de suprir a falta de suporte do órgão acusador e evitar que os crimes ficassem sem uma providência eficaz (levando em consideração que o magistrado já não poderia atuar de ofício), o legislador criou meios de auxiliar o Ministério Público, dentre eles, o promotor ad hoc (já revogado) e o assistente de acusação. (SILVÉRIO JÚNIOR, 2006).

Aury Lopes Junior traz o conceito da figura do assistente de acusação da seguinte forma:

O assistente de acusação é uma parte secundária, acessória, contingencial, pois o processo independe dele para existir e se desenvolver. É, assim, recorrente dizer-se que sua natureza jurídica é de parte contingente, secundária. É uma parte, mas não principal, pois sua atividade processual é acessória em relação àquela desenvolvida pela parte principal, que é o Ministério Público. (LOPES JÚNIOR, 2017, p. 564).

O Código de Processo Penal traz toda a regulamentação e atribuições do Assistente do Ministério Público, entre elas a legitimidade (art. 430 do CPP), o procedimento de habilitação (art. 272 do CPP), a proposição dos meios de prova, e ainda a possibilidade de efetuar perguntas às testemunhas, participar de debate oral, arrazoar recursos por ele interpostos ou pelo Ministério Público (art. 271 do CPP), além de requerer prisão preventiva (art. 311 do CPP).

Quanto à possibilidade para interposição de recurso, inicialmente destacamos que o assunto deve ser analisado sob uma ótica constitucional do instituto. Contudo, para fim didático e, a fim de se chegar ao ponto chave do presente artigo, neste momento importa-nos apenas destacar que o Código de Processo Penal prevê que o assistente de acusação recorra: a) da decisão de impronúncia; b) do julgamento de extinção da punibilidade; 
c) da sentença absolutória (artigo 598); d) sentença condenatória visando aumento da pena. (LOPES JUNIOR, 2017).

A doutrina e jurisprudência contemporânea apresentam divergências sobre determinados pontos que englobam o instituto, dentre eles destacamos a decisão prolatada pelo Tribunal de Justiça de Alagoas, no Recurso em Sentido Estrito n. 000521421.2012.8.02.0001, que reconheceu a legitimidade da Defensoria Pública em atuar como assistente de acusação.

Neste sentido, destacou o desembargador do caso, João Luiz Azevedo Lessa:

Declarar a impossibilidade de tal atuação seria restringir um direito da vítima e seus familiares, que, decerto, são atingidos pelas disposições constitucionais, ao considerar a própria literalidade do caput do artigo $5^{\circ}$ de nossa Carta Magna, onde registra que todos são iguais perante a lei, não existindo distinção legal em razão da condição econômico-social das partes de processos judiciais. (ALAGOAS, 2015).

Em contrapartida, Lênio Luiz Streck, questiona se a Defensoria Pública realmente possui tal legitimidade:

Qual é o papel das instituições em uma democracia? Vamos complicar um pouco o exemplo, supondo que esse assistente de acusação seja um defensor público. Pronto: temos o prato feito. No primeiro exemplo, o Estado, que tem um agente político com a garantia da vitaliciedade e que possui o monopólio da ação penal pública, ao mesmo tempo admite que possa haver um "auxílio" de "terceiro interessado" para essa tarefa. Já no segundo caso, o Estado paga - caro - duas vezes: para acusar e para "auxiliar" a acusação. Se no primeiro caso até poderíamos dizer que, afinal, quem paga é o particular, no segundo caso temos uma esquizofrenia institucional: em um país carente de recursos, o Estado-se-dá-ao-luxo-de-pagar-duas-acusaçõespúblicas [...] Daí a pergunta: podemos transferir recursos do restante da população para pagar um defensor que irá fazer a assistência da acusação em nome de uma 
vítima em particular, sem que possamos estender esse direito para todas as demais vítimas de terrae brasilis? Ou seja: se uma vítima tem direito a um defensor fazendo a assistência de acusação, devemos ter presente que todas as demais vítimas devem ter o mesmo direito. Elementar isso também. Logo, haveria dois agentes do Estado acusando réus [...]. (STRECK, 2014, grifo nosso).

Entretanto, não é somente na esfera infraconstitucional que a doutrina e jurisprudência apresentam divergência sobre o assistente do Ministério Público, mas a própria constitucionalidade da existência do instituto é questionada, conforme veremos a seguir.

\subsection{O assistente do ministério público: doutrina e jurisprudência}

De plano, destacamos que os posicionamentos da doutrina majoritária e dos tribunais superiores apontam que a figura do assistente de acusação foi recepcionada pela Carta Constitucional de 1988 por dois fundamentos: a) futura ação civil exdelicto; b) justa aplicação da lei penal.

Sobre a justificativa de permanência do assistente, em virtude de futura ação civil exdelicto, Fernando da Costa Tourinho Filho leciona:

Segundo dispõe o art 91, I, do CP, constitui um dos efeitos da sentença penal condenatória tornar certa a obrigação de indenizar o dano causado pelo crime. Por isso mesmo dispõe o art., 63 do CPP que, "transitada em julgado a sentença condenatória, poderão promover-lhe a execução, no juízo cível, para o efeito da reparação do dano, o ofendido, seu representante legal ou seus herdeiros". Nesse caso, a sentença constitui titulo certo e ilíquido em favor do direito à indenização, e, com esse título executório, o exequente não vai discutir o andebeatur, mas sim o quantum debeatur. Desse modo, salta aos olhos que o Estado permitiu pudesse o ofendido ingressar no Processo 
Penal nos crimes de ação pública, para velar pelo seu direito à indenização. Aplica-se à espécie o ensinamento de Florêncio de Abreu: "O recurso facultado ao assistente funda-se precipuamente no direito, que se lhe não pode negar, de opor-se a uma decisão de primeira instância, prejudicial ao seu legítimo interesse ao ressarcimento do dano causado pelo delito, atenta a influência soberana do juízo penal sobre o civil”. Conclui-se, pois, que a função do assistente não é a de auxiliar a acusação, mas a de procurar defender seu interesse na indenização do dano exdelicto. (TOURINHO FILHO, 2010, p. 602, grifo nosso).

Já o outro posicionamento doutrinário e jurisprudencial que reconhece a figura do assistente de acusação constitucional está vinculado à cooperação com a justiça que o instituto estabelece, o qual busca a justa aplicação da lei penal. (LIMA, 2017).

Nesse sentido é o entendimento de Ada Pellegrini Grinover, Antônio Magalhães Gomes Filho e Antônio Scarance Fernandes:

Pensamos, porém, que o assistente de acusação também intervém no processo com a finalidade de cooperar com a justiça, figurando como assistente do MP ad coadjuvandum. Assim, com relação à condenação, o ofendido tem o mesmo interesse-utilidade da parte principal na justa aplicação da pena. Já com relação à revogação de benefícios penais, como sursis, a atividade de colaboração do ofendido com a justiça esgota-se, no nosso sistema processual, com a condenação (art. 598, CPP), não se podendo vislumbrar seu interesse na modificação de benefícios inerentes à execução da pena. (GRINOVER, GOMES FILHO; FERNANDES, 1996).

Ademais, o Supremo Tribunal Federal, ao enfrentar o tema sobrea constitucionalidade do assistente, no HC n.102 085/RS, por maioria dos votos também consolidou o posicionamento, considerando a figura do assistente de acusação constitucional, justamente pelos fundamentos da futura ação civil ex delicto e 
interesse do ofendido,na justa aplicação da pena.

Todavia, o plenário do STF ao fundamentar a recepção do assistente do Ministério Público, em momento algum destacou que a criação do instituto foi desenvolvida para auxiliar o órgão do estado acusador, que naquele momento histórico não se encontrava devidamente estruturado. Portanto, consideramos que a figura do assistente de acusação deve ser repensada nesse sentido, uma vez que o órgão acusador, além de exercer uma função privativa, tem a seu favor todo amparo estatal, dispondo de promotores devidamente capacitados com carreiras similares da magistratura. (SILVÉRIO JÚNIOR, 2006).

Nesse sentido, parcela da doutrina (minoritária) compreende que o assistente é o desvirtuamento das características atribuídas ao processo penal contemporâneo, tendo em vista que o seu ingresso na ação (embora os frágeis argumentos que a doutrina e jurisprudência levantam) é motivado pelas paixões da vingança privada do particular, que em nada contribuem para um processo penal equilibrado e ético, com características do sistema acusatório. (POLASTRI LIMA, 2013).

Nesse sentido, Lênio Streck leciona:

Trata-se da insistência em prever uma figura incompatível com o sistema acusatório e com a própria Constituição, especialmente se entendermos a extensão da previsão de que o Ministério Público é o titular da ação penal pública, recebendo, para tanto, as garantias da magistratura. $O$ assistente de acusação nada mais é do que a ratificação de uma realidade dos anos 40 do século $\mathrm{XX}$ : um país marcado por contradições e um Ministério Público visto apenas como órgão de acusação a serviço dos interesses das camadas dominantes da sociedade. (STRECK, 2009 p. 135, grifo nosso).

O assistente do Ministério Público é um resquício do sistema utilizado nas sociedades primitivas, quando prevalecia a vingança do particular, em que se permitia à violência do imputado, 
sem controle e programação. (POLASTRI LIMA, 2013).

Entretanto, em um momento histórico definido, o Estado assumiu o monopólio da jurisdição por meio de instituição própria e, além desta instituição acusatória em 1940 não estar devidamente instalada (conforme ressaltamos), permaneceram resquícios da justiça privada em nosso ordenamento jurídico, dentre eles, o promotor ad hoc (já revogado), a ação penal privada (para delitos em que o interesse do Estado encontra-se em seguindo plano) e o assistente de acusação. (SILVÉRIO JÚNIOR, 2006).

Como se vê, a inconstitucionalidade do assistente de acusação não só se justifica pelos elementos jurídicos, como pelos fundamentos sócios políticos, como precisamente destaca Lênio Luiz Streck:

Não se pode admitir, no momento em que se caminha mais e mais em uma direção do Direito Público, um retrocesso que sustente aspectos privados no processo penal. A figura do assistente de acusação é condizente com um modelo histórico. Com o advento do Estado Democrático de Direito, o direito passa a ter um perfil promovedor transformador. Por isso, a defesa do direito individual deve dar passagem à defesa dos direitos sociais e coletivos. (STRECK, 2001, p. 159, grifo nosso).

Nesse quadro, seguindo uma interpretação sistemática da Carta de 1988, verifica-se que o assistente não está somente em contrassenso com o artigo 129, inciso I da CF, mas também confronta o princípio do contraditório adotado no sistema acusatório.

No processo penal o contraditório deve ser analisado de uma forma distinta do contraditório do âmbito do processo civil. Aqui, o contraditório deve ser destacado como um contraditório efetivo, com ampla defesa ao acusado, pressupondo paridade de armas entre as partes.

Nesse sentido, João Porto Silvério destaca: 
O Ministério Público não precisa de auxiliar no exercício da ação penal pública, quer porque não necessite de ajuda, quer em virtude da flagrante violação do princípio do contraditório, que exige o uso de armas com o mesmo poder de fogo. À vista de uma interpretação sistemática da Constituição de 1988, não vejo como continuar subsistindo a figura do assistente de acusação na atual sistemática processual penal, por não terem sido recepcionados em virtude da incompatibilidade patente. (SILVÉRIO, 2006, p. 345, grifo nosso).

No mesmo sentido, leciona Salo de Carvalho:

Assim, durante os procedimentos instrutórios, o protagonismo será exercido através do concurso ativo das partes. Acusação e defesa, em paridade de armas, movimentam-se no debate do jogo processual para dar substância às hipóteses processuais proibitoriamente construídas. (CARVALHO, 2013, p. 165-166, grifo nosso).

Ora, o assistente de acusação, da maneira como ele foi projetado pelo Código Processual Penal e, da maneira que ele foi construído pela jurisprudência e parte da doutrina, acrescenta e muito à acusação, causando desequilíbrio entre as partes e afetando diretamente o sistema acusatório acolhido pela Constituição Federal.

\subsection{A inconstitucionalidade do artigo 598 do Código de Processo Penal}

Outro ponto a ser discutido está na previsão contida no artigo 598 do CPP, que confere ao assistente a possibilidade de promover eventuais recursos.

Segundo o artigo 598 do referido diploma legal:

Art. 598. Nos crimes de competência do Tribunal do Júri, ou do juiz singular, se da sentença não for interposta apelação pelo Ministério Público no prazo legal, o ofendido ou qualquer das pessoas enumeradas no art. 31 , ainda que não se tenha habilitado como assistente, poderá interpor apela- 
ção, que não terá, porém, efeito suspensivo.

Conforme anteriormente mencionado, ao enfrentar este tema, o STF, no HC n.102.085/RS, recepcionou o artigo 598 do CPP basicamente pelos motivos anteriormente destacados: a) futura interposição de ação civil exdelicto; b)interesse do ofendido; c) por considerar que o monopólio da ação penal previsto no artigo 129, inciso I da CF não é absoluto.

Assim, para que possamos detalhar com precisão a presente discussão, daremos destaque a cada um dos pontos levantados acima.

Destacam-se como frágeis os fundamentos levantados pela doutrina e jurisprudência contemporânea,que defendem a permanência do assistente em razão da influência decisiva que a sentença penal condenatória exerce no campo cível.

Isto porque tal interesse deve ser analisado em seara própria, por meio de ação civil ex delict

[...] que pode ser intentada ainda que a ação penal não tenha sido proposta, ou já proposta e estiver em curso (CP, art. 91, I), cabendo ao juiz fixar valor mínimo para a reparação dos danos causados pela infração ex officio, independentemente de haver requerimento do assistente. (LIMA, 2017, p. 1216).

Sobre o tema, se faz imprescindível destacar o posicionamento de Aury Lopes Júnior:

Noutra dimensão, o interesse econômico deve ser satisfeito com plenitude, mas não no processo penal. A mistura de pretensões (acusatória indenizatória) gera uma grave confusão lógica e, principalmente, um hibridismo bastante perigoso e problemático, que pode deduzir a "condenações penais disfarçadas de absolvições fáticas", ou seja, condena-se alguém na esfera penal a uma pena irrisória (multa ou restritiva de direito), muitas vezes por delitos insignificantes, pois no fundo o que se quer satisfazer é a pretensão indenizatória. Isso representa um desvirtuamento completo do sistema jurídico penal para a satis- 
fação de algo que é completamente alheio a sua função. (LOPES JÚNIOR, 2017, p. 568).

Ou seja, tal argumento não justifica a participação do assistente de acusação no processo penal, uma vez que o ofendido poderá ingressar no juízo cível, inclusive com maior extensão, dando em conta que nesta seara o patrimônio do ofendido será discutido com mais abrangência que no juízo penal. (STRECK, 2001).

No que pertine ao fundamento que destaca o interesse do ofendido, a doutrina predominante e a jurisprudência dos Tribunais Superiores destacam que o assistente do Ministério Público poderá recorrer, se transcorrido o prazo do órgão ministerial e este não tiver realizado a promoção de recurso. Entretanto, a jurisprudência e a doutrina vão além, pois entendem que ao assistente é facultado a interposição do recurso, mesmo que o órgão ministerial entenda manifestar-se pelo pedido de absolvição do acusado.

Em que pese tais manifestações, estes posicionamentos encontram-se em um lado oposto daquele apontado pela Constituição Federal de 1988. Se os fundamentos buscam "[...] um interesse na justa aplicação da pena", a pergunta que deve ser feita é: "[...] qual conceito de justiça é esse que somente se conforma com a sentença condenatória? [...] Sim, porque ninguém se habilita como assistente para postular a absolvição do acusado." (LOPES JÚNIOR, 2014, p. 789). Ademais, "Se o réu é acusado pela sociedade e essa não tem interesse, qual a razão para a vítima intervir na ação?’ (STRECK, 2014).

Como se vê, no âmbito do processo penal não há que se falar em interesse do assistente, considerando que ele simplesmente ocupa a posição auxiliar do titular da ação penal.

Nesse sentido, é o voto do ex-ministro do Supremo Tribunal Federal, Cesar Peluso, no HC n. 102.085, merece destaque: 
[...] o texto constitucional derrogou a velha concepção de justiça privada e, por isso, deferiu ao Ministério Público, em caráter privativo e exclusivo, a titularidade da ação penal "Para quê? Para a defesa de interesse estatal específico, que é o de punir criminosos [...]. De modo que nem sequer se pode cogitar de que haja, nisso, algum interesse estatal em defender interesses patrimoniais do ofendido. Em segundo lugar, porque costuma acontecer, como em qualquer instituição, que os agentes às vezes falhem, nos casos em que eventualmente o Ministério Público se omita, dada a relevância do mesmo interesse estatal, a Constituição atribuiu a titularidade da ação ao particular ofendido, mas em caráter de exceção e apenas na hipótese de omissão. [...] Só pode agir em termos de recurso quem tem direito de ação, direito de agir. Ora, quem tem direito de agir? O Ministério Público, como regra, e o querelante, como exceção, não o assistente. $O$ assistente não exerce direito de ação, nem na concepção do processo criminal, nem na concepção, muito mais generosa, da ação civil. $\mathrm{O}$ assistente simplesmente adere ao titular da ação. [...] Ora, o assistente penal, não sendo titular de ação nenhuma, senão assistente de quem o é, a meu ver não pode recorrer. (BRASIL, 2010, grifo nosso).

Dessa forma, levando em consideração que o recurso é apenas uma continuidade da ação, que já foi interposta por meio de uma denúncia e, portanto, não ocorrendo à inércia por parte do Ministério Público, não há que se falar em interesse do assistente de acusação.

Ademais, uma ação penal de iniciativa pública, originada por meio de uma atuação ministerial em forma de denúncia, na qual não houve inércia do titular da ação, não pode simplesmente transformar-se em uma ação penal privada. Isto ocorre justamente quando há esta "substituição" nos casos em que o Ministério Público se satisfaz com a sentença aplicada pelo juízo, ou manifesta-se pela absolvição do acusado, e, posteriormente o assistente de acusação, movido pelo seu "interesse", recorre dessa sentença nos termos do artigo 598 do Código 
de Processo Penal. (STRECK, 2015).

Este foi o entendimento do ministro do Supremo Tribunal Federal, Marco Aurélio no HC 102.085, quando denominou tal substituição como "corrida de revezamento", conforme se destaca:

O que nos vem da Carta de 1988? Todos sabemos que se deu ênfase muito grande à atuação do Ministério Público na defesa da sociedade. Há diversos incisos no artigo 129 a versar sobre a propositura de ações. No tocante à atividade precípua do Ministério Público - a propor a ação penal publica-o texto legal refere-se à atuação privativa, ao contrário do que ocorre no tocante, por exemplo, inquérito civil, à ação civil pública e a ação de inconstitucionalidade. Então o próprio constituinte abriu uma exceção única à regra da promoção da promoção privada em substituição à Ação Penal Pública do Estado acusador. Fe-lo de forma exauriente mediante o preceito do inciso, muito já referido LIX do artigo 5, que revela o principal rol das garantias constitucionais dos cidadãos. Apenas versou não a propositura da ação penal pública incondicionada, mas, em substituição, ante a inércia do Ministério Público, a da privada: Art. $5^{\circ}$ [...] LIX - será admitida ação privada nos crimes de ação pública, se esta não for intentada"- está em bom português - "no prazo legal" Foi ou não intentada? Foi, mas, ante o contexto, manifestou-se o Ministério Público, em alegações finais, pela absolvição. Será que, diante desses dois dispositivos, é possível ter-se a transmudação da ação penal pública que existiu em uma ação penal privada? A resposta para mim, é desenganadamente negativa. Uma ação que nasce pública incondicionada, não pode, na fase recursal, transformar-se em uma ação penal privada. Esta transformação ocorrerá, vingando a óptica majoritária, a partir do momento em que não se conte mais, na fase recursal, na angularidade processual, com a participação do titular da ação o Ministério Público. Por isso Presidente, tenho que a Carta de 1988 não recepcionou o artigo 598 do Código de Processo penal [...]. (BRASIL, 2010, grifo nosso). 
O tema torna-se ainda mais polêmico quando o próprio órgão acusador pede a absolvição do réu e o assistente (por meio de seu interesse) pleiteia a condenação, conforme exemplificado por meio de um caso concreto destacado por Lenio Streck:

Em um dos julgamentos mais rumorosos dos últimos anos em Porto Alegre - caso dos colonos "sem terra" acusados da morte de um policial militar, realizado nos dias 24,25 e 26 de junho de 1992, isso ficou bem nítido. Enquanto o Ministério Público desenvolveu um trabalho mais técnico, preocupado com a prova dos autos, $o$ assistente de acusação calcou-se muito mais na retórica. Podê-sedepreender, daí a clara diferença de que poderia se chamar de acusação stricto sensu feita pelo Ministério Público e uma acusação por lato sensu - desenvolvida pelo assistente de acusação, mais preocupado com a pessoalização do caso. (STRECK 2001, p. 159).

Como afirma Marcellus Polastri Lima (2013), na prática o ofendido pouco se importa com a reparação do dano ou aplicação de uma pena justa, mas sim, o seu interesse é exclusivamente oriundo da vingança privada.

Por fim, o terceiro fundamento do STF que reconheceu o assistente como parte legitima para interpor recurso, está vinculado ao que dispõe o artigo 129, inciso I da CF. Para os ministros que decidiram pela recepção do artigo 598 do CPP, o Ministério Público não exerce o monopólio exclusivo da ação penal, isto porque o artigo $5^{\circ}$, inciso LIX da CF prevê a possibilidade de ofendido atuar nas hipóteses de inércia do órgão acusador.

Ocorre que,apesar de a figura do assistente de acusação assemelhar-se com a do querelante, torna-se fundamental a distinção entre ambos.

Enquanto o querelante (em razão da inércia do Ministério) é o titular da ação penal privada subsidiária da pública, exercendo o polo ativo de tal relação jurídica, o assistente de acusação simplesmente adere uma função de auxílio e não de 
autor da ação penal de iniciativa pública, seja ela incondicionada ou condicionada.

Em outras palavras, não se pode invocar o artigo $5^{\circ}$, LIX, da Constituição Federal, quando o Ministério Público não foi inerte e pede a absolvição, ou deixa de interpor recurso em razão de sua conformidade com eventuais decisões prolatadas.

A nosso ver, a titularidade para interposição de recurso está atrelada a quem exerce o direito de ação, que no Processo Penal como regra é o MP e, como exceção,a vítima como querelante. Não há que se falar em direito de ação do assistente, pois este simplesmente adere uma postura de auxiliar do órgão acusador, fruto de um momento histórico distante do atual. (SILVÉRIO JÚNIOR, 2006).

Desse modo, diante da flagrante inconstitucionalidade do artigo 598, do Código de Processo Penal, ressalta-se que o termo expressado como "inconstitucionalidade" deve ser entendido como norma não recepcionada, uma vez que não há de se falar em norma inconstitucional anterior à Constituição Federal (como é o caso do artigo 598, do Código de Processo Penal, editado ao tempo do Estado novo), mas sim, de sua não recepção, ou seja, havendo esse conflito entre uma norma infraconstitucional anterior ao conteúdo da nova Carta Magna, ocorre o fenômeno da revogação implícita, ou inconstitucionalidade superveniente como destaca a doutrina. (MENDES; BRANCO, 2015).

Diante do exposto, percebe-se que a atuação do assistente do Ministério Público deve ser rediscutida pela comunidade jurídica, sob uma perspectiva voltada ao processo penal contemporâneo, com um olhar pautado no sistema acusatório e nos princípios que regem o devido processo penal. Devemos ainda nos desvincular dos conceitos antigos e interpretar o supracitado artigo sob a perspectiva constitucional, deixando de 
lado, também, a errônea tese do direito processual jurisprudencializado, que vem se aplicando com menos regras e mais jurisprudência. (STRECK, 2012).

\section{CONCLUSÃO}

O presente artigo desenvolveu-se com o objetivo central de analisar a legitimidade que detém o assistente de acusação,de interpor recurso no processo penal brasileiro, uma vez que o artigo 598, do Código de Processo Penal, lhe conferiu nos casos de omissão do Ministério Público esta possibilidade.

Observou-se que o posicionamento predominante, tanto da doutrina quanto da jurisprudência, é que a figura do assistente de acusação foi plenamente recepcionada pela Constituição Federal, pelos seguintes motivos: a) recomposição aos danos patrimoniais sofridos pelo ofendido, b) interesse em uma justa aplicação da pena.

Por outro lado, apontou-se também que uma posição minoritária da doutrina entende que a figura do assistente de acusação não foi recepcionada pela Constituição Federal de 1988, e que as razões condizentes com a sua atuação não justificam a sua permanência no processo penal brasileiro.

Com relação à recomposição do dano do ofendido, ressaltou-se que tais prejuízos não devem ser desamparados à vítima, no entanto, devem ser discutidos em seara própria, ou seja, no âmbito do direito civil.

No que diz respeito ao interesse em uma justa aplicação da pena, tal argumento também não se mantém. Isto porque, conforme já destacado, o instituto da assistência de acusação foi criado para exercer a função do órgão acusador, numa época em que o Ministério Público não se encontrava devidamente estruturado para agir como defensor da sociedade. Contudo, a Constituição Federal de 1988 conferiu um leque 
de atribuições ao órgão ministerial, com destaque para a função de atuar de maneira privativa nas ações penais de iniciativa pública, que extinguiu do particular a possibilidade de dar início à ação e atos subsequentes.

Chegando ao ponto chave deste artigo, destacou-se que a fundamentação utilizada pela doutrina e pela jurisprudência predominante (inclusive pelo Supremo Tribunal Federal) é de que ao assistente do Ministério Público, é facultada a interposição de recurso nos termos do artigo 598, do Código de Processo Penal, em razão de seu interesse na justa aplicação da pena.

No entanto, embora tais argumentos impressionem a esmagadora doutrina e jurisprudência, após grande reflexão e, diante do trajeto percorrido neste estudo, sob análise do processo penal contemporâneo e sob a égide do sistema acusatório, princípios constitucionais e, por fim, da própria Constituição Federal, conclui-se que o assistente de acusação é parte ilegítima para interpor recurso no processo penal brasileiro nos termos do artigo 598, do Código de Processo Penal, e, que em razão disso, o referido artigo não foi recepcionado pela Constituição Federal de 1988.

Da mesma forma, ressaltou-se que uma ação penal de iniciativa pública não pode transformar-se em uma ação penal privada. Isto ocorre justamente quando o órgão Ministerial, satisfeito com a sentença absolutória prolatada pelo juízo ou em sede de alegações finais postula pela absolvição do acusado e, o assistente de acusação, movido pelo interesse de vingança privada, recorre sem a participação do órgão constitucionalmente incumbido em realizar tal função. Portanto, afrontando diretamente o sistema acusatório que prevê uma acusação regida pelos princípios que o norteiam, dentre eles, o contraditório (paridade de armas).

Assim, como o próprio Código de Processo Penal prevê 
(art. 598) que assistente somente poderá interpor recurso nas situações de inércia do órgão acusador e, conforme destacamos no presente artigo, esta única hipótese foi derrogada pela Constituição Federal de 1988, conclui-se, também com base nos argumentos supracitados, que a figura do assistente do Ministério Público não foi recepcionada pela Constituição Federal de 1988, em que pese posicionamento contrário de parte da doutrina e jurisprudência do Supremo Tribunal Federal.

\section{REFERÊNCIAS}

ALAGOAS. Tribunal de Justiça. Apelação n. 0005214-21.2012.8.02.0001, da câmara criminal. Relator: Des. João Luiz Azevedo Lessa. Alagoas. 27 de maio de 2005. Disponível em: <http://tjal.jusbrasil.com.br/jurisprudencia/192666914/recursoem-sentido-estrito-rse-52142120128020001-al-0005214-2120128020001/inteiroteor-192666945>. Acesso em: 30 out. 2015.

AVENA, Norberto Cláudio Pâncaro. Processo penal: esquematizado. 9. ed. Rio de Janeiro: Forense: São Paulo: Método, 2017.

BRASIL. Código de processo penal (1941). VadeMecum compacto. 22. ed. São Paulo: Saraiva, 2018.

. Constituição da República Federativa do Brasil (1988). VadeMecum compacto. 25. ed. São Paulo: Saraiva, 2018.

. Supremo Tribunal Federal. Habeas Corpus n. ${ }^{\circ}$ 102.085/RS, Plenário. Relatora Ministra Carmen Lúcia, Brasília, DF, j. 27 out 2010. Disponível em: <http://redir.stf. jus.br/paginadorpub/paginador.jsp?docTP $=\mathrm{TP} \&$ docID $=3921248>$. Acesso em: 3 set. 2016.

BONFIM. Edilson Mougenot. Curso de processo penal. 12. ed. São Paulo: Saraiva, 2017.

BOSCHI, José Antonio P. Ação penal. Rio de Janeiro: AIDE Editora, 1997.

CARVALHO, Salo de. Antimanual de criminologia. 5. ed. São Paulo: Saraiva, 2013.

FERRAJOLI, Luigi. Direito e razão: teoria do garantismo penal. São Paulo: Revista dos Tribunais, 2002.

GRECCO FILHO, Vicente. Manual de processo penal. 8. ed. São Paulo: Saraiva, 2010.

GRINOVER, Ada Pelegrini. Gomes Filho, Antonio Magalhães, Fernandes, Antonio Scarance. Recursos no processo penal. São Paulo: Editora RT, 1996.

LIMA, Renato Brasileiro de. Manual de processo penal. 5. ed. Salvador: Juspodivm, 2017.

LOPES JUNIOR, Aury. Direito processual penal e sua conformidade constitucional. 9. ed. São Paulo: Saraiva, 2014.

. Direito processual penal e sua conformidade constitucional. 9. ed. São Paulo: 
Saraiva, 2017.

. Fundamentos do processo penal introdução crítica. São Paulo: Saraiva, 2015.

MARQUES, José Frederico. Elementos de direito processual penal. 2. ed. Campinas: Millennium, 2000.

MAZZILI, Hugo Nigro. Regime jurídico do Ministério Público. 2. ed. São Paulo: Saraiva, 2007.

MENDES, Gilmar Ferreira; Branco, Paulo Gustavo Gonet. Curso de direito constitucional. 10. ed. São Paulo: Saraiva 2015.

OLIVEIRA, Eugênio Pacelli de. Curso de processo penal. 10. ed. Rio de Janeiro: Lumen Juris, 2017.

LIMA, Marcellus Polastri, Manual de processo penal. 7. ed. Rio de Janeiro: Lumen Juris, 2013.

PRADO, Geraldo. Sistema acusatório: a conformidade constitucional das leis processuais penais. 4. ed. Rio de Janeiro: Lumen Juris, 2006.

RANGEL Paulo. Direito processual penal. 24. ed. São Paulo: Atlas, 2016.

STRECK, Lenio Luiz. Novo código de processo penal: o problema dos sincretismos de sistema (inquisitorial e acusatório). Brasília: 7 jul. 2009. Disponível em: $<$ http://www2. senado.leg.br/bdsf/item/id/194936>. Acesso em: 8 nov. 2015.

. O passado, o presente e o futuro do STF em três atos consultor jurídico. São Paulo: 15 nov. 2012. Disponível em: <http://www.conjur.com.br/2012-nov-15/sensoincomum-passado-presente-futuro-stf-tres-atos $>$. Acesso em: 1 fev. 2015.

Promotor quer absolvição e advogado condenação: que jabuticaba é essa?. Consultor jurídico. São Paulo: 24 de jul. 2014. Disponível em: $<$ http://www.conjur. com.br/2014-jul-24/senso-incomum-promotor-requer-absolvicao-defensor-condenacao-jabuticaba>. Acesso em: 2 fev. 2015. gado, 2001.

Tribunal do júri símbolos e rituais. 4. ed. Porto Alegre: Livraria do Advo-

SILVÉRIO JÚNIOR, João Porto. “A incompatibilidade do assistente de acusação com o processo acusatório de 1988”. Revista Jurídica. Porto Alegre, n. 345, p. 93, jul. 2006.

SOUZA, Motauri Ciocchetti de. Ministério Público e o princípio da obrigatoriedade. 2. ed. Método, 2007.

TOURINHO FILHO, Fernando da Costa. Manual de processo penal. 13. ed. São Paulo: Saraiva, 2010.

ZILLI, Marcos Alexandre Coelho. A iniciativa instrutória do juiz no processo penal. São Paulo: Revista dos Tribunais, 2003.

Recebido em: 28/05/2018

Aprovado em: 07/08/2018 